Volume 6 Issue 1, 2020

P-ISSN : 2528-360X, E-ISSN : 2621-6159

Website: https://www.jurnal-umbuton.ac.id/index.php/Pencerah

\title{
Uji Kuat Tekan Beton dengan Menggunakan Pasir Kali Desa Rongi Kec. Sampolawa Kab. Buton Selatan
}

\author{
${ }^{1}$ Muh. Sayfullah S, ${ }^{1}$ Musrifin, ${ }^{1}$ Alon Saputra
}

Email: muh.sayfullahs@gmail.com

\begin{abstract}
This study aims to determine the characteristics of fine aggregate material characteristics originating from Rongi Village, Sampolawa Subdistrict, coarse aggregate originating from Badene Village, Batauga Subdistrict, and to determine the compressive strength produced by concrete against the mixture of materials using fine aggregate originating from Rongi Village and coarse aggregate comes from the Badene Village of Batauga District. In this study the material was mixed using water with a cement water factor of 0.59. The compressive strength test is carried out at the age of 3 days, 7 days and 28 days, with a slinder size of $15 \mathrm{~cm} \times 30 \mathrm{~cm}$. The sample of specimens in this study amounted to 15 pieces. From the results of tests carried out the compressive strength value of the concrete produced using fine aggregate material derived from Rongi Village and coarse aggregate originating from the Village of Sangatene that is an average at 3 days of $94.5 \mathrm{~kg} / \mathrm{cm} 2$, age 7 days is $119.6 \mathrm{~kg} / \mathrm{Cm} 2$, and age 28 days is $192.5 \mathrm{~kg} / \mathrm{cm} 2$. Based on the results of the compressive strength test shows that the compressive strength value obtained is increasing with increasing age of the treatment of the test specimens.

Keywords: Aggregate; Concrete; Sand; Gravel; Sea Water
\end{abstract}

\begin{abstract}
Abstrak
Penelitian ini bertujuan untuk mengetahui sifat-sifat karakteristik material agregat halus yang berasal dari Desa Rongi Kecamatan Sampolawa, agregat kasar yang berasal dari Desa Burukene Kecamatan Batauga dan untuk mengetahui nilai kuat tekan yang dihasilkan oleh beton terhadap campuran material yang menggunakan agregat halus berasal dari Desa Rongi dan agregat kasar berasal dari Desa Burukene Kecamatan Batauga. Dalam penelitian ini material dicampur menggunakan air dengan faktor air semen yaitu 0.59. Pengujian nilai kuat tekan dilakukan pada umur perawatan 3 hari, 7 hari dan 28 hari, dengan ukuran benda uji slinder $15 \mathrm{~cm} \times 30 \mathrm{~cm}$. Sampel benda uji dalam penelitian ini berjumlah $15 \mathrm{buah}$. Dari hasil pengujian yang dilakukan nilai kuat tekan beton yang dihasilkan dengan menggunakan material agregat halus yang berasal dari Desa Rongi dan agregat kasar yang berasal dari Desa Burukene yaitu rata-rata pada umur 3 hari sebesar $94.5 \mathrm{Kg} / \mathrm{Cm} 2$, umur 7 hari sebesar $119.6 \mathrm{Kg} / \mathrm{Cm} 2$, dan umur 28 hari sebesar $192.5 \mathrm{Kg} / \mathrm{Cm} 2$. Berdasarkan hasil uji kuat tekan menunjukan bahwa nilai kuat tekan yang diperoleh semakin meningkat seiring dengan bertambahnya umur perawatan benda uji.

Kata Kuci: Beton; Agregat; Pasir; Batu Kerikil; Air Laut
\end{abstract}

\section{PENDAHULUAN}

Penggunaan beton sebagai bahan dasar dalam dunia konstruksi sudah lama dikenal di Asia Tenggara khususnya Indonesia serta merupakan salah satu bahan utama yang sering dipakai pada pembuatan pekerjaan konstruksi bangunan. Beton adalah suatu material

\footnotetext{
${ }^{1}$ Universitas Muhammadiyah Buton, Indonesia
}

hasil dari campuran agregat (agregat kasar dan agregat halus), air, semen dan bahan tambah yang bervariasi.

Bahan penyusun beton salah satunya adalah agregat halus (pasir). Dalam perkembangan zaman sekarang ini kebutuhan pasir dalam proses pelaksanaan pekerjaan yang memenuhi standar mutu dalam penggunaannya 
sudah mulai berkurang, terutama pada kota-kota besar atau pada negara-negara berkembang. Dalam dunia teknik sipil terutama pada negara maju telah memikirkan tentang tantangan kedepan akan semakin berkurangnya jumlah agregat yang dapat digunakan sebagai bahan dasar pada campuran beton, terlebih pelaksanaan pekerjaan kontruksi bangunan semakin meningkat sehingga penggunaan agregat juga yang semakin meningkat.

\section{KAJIAN PUSTAKA}

\subsection{Pengertian Umum Beton}

Beton adalah hasil campuran beberapa material yaitu antara semen portland atau semen hidrolik yang lain, agregat halus (pasir), agregat kasar (kerikil) dan air, tanpa atau dengan menggunakan bahan tambahan yang membentuk massa padat dalam pencampuran (SNI-03-2847-2002). Seiring dengan penambahan umur, hari pertama sampai dengan hari pelaksanaan pengujian maka beton akan semakin mengeras dan akan mencapai nilai kekuatan rencana $\left(f^{\prime} c\right)$ pada usia 28 hari (Tjokrodimuljo, K.1996)

Kabupaten Buton merupakan daerah yang banyak memiliki sumber daya alam. Salah satunya material yang merupakan bahan penyusun beton yang ada di Kecamatan Sampolawa. Namun dari segi material kita perlu mengetahui sifat fisik material itu sendiri. Sehingga kita dapat memilih tempat pengambilan material sesuai dengan kebutuhan kita. Salah satu contoh lokasi yang memiliki sumber daya alam agregat kasar dan agregat halus terdapat di Desa Rongi Kecamatan Sampolawa.

Secara umum kelebihan dan kekurangan beton adalah:

a. Kelebihan penggunaan beton:

1) Dapat dengan mudah dibentuk sesuai dengan model dan kebutuhan konstruksi
2) Dapat memikul dan menahan beban yang berat

3) Tahan pada temperatur tinggi

4) Biaya pemeliharaan kecil.

b. Kekurangan penggunaan beton

1) Bentuk dan pola yang telah dibuat sulit diubah

2) Dalam pelaksanaan pekerjaan memerlukan ketelitian yang tinggi

3) Memiliki bobot yang berat

4) Memiliki daya pantul suara yang keras atau tidak kedap suara.

\subsection{Bahan PenyusunBeton}

Untuk mengetahui prilaku pada beton maka diperlukan pengetahuan tentang sifat-sifat karakteristik masingmasing material.

\section{a. Semen Portland}

Pada tahun 1824 Joseph Aspidin adalah seseorang yang pertama kali mengusulkan nama Portland Cemen. Langkah-langkah yang harus dilalui untuk membuat Portland Semen, sehingga sangat halus dan memiliki sifat adhesive maupun kohesif. Semen diperoleh dengan menggunakan cara membakar bersamaan suatu campuran yang mengandung kalsium karbonat atau batu gamping dan Argilaceous (yang mengandung alumina) dengan menggunakan perbandingan tertentu. Beberapa kandungan semen Portland terdiri dari kapur, silica, alumina. Semua bahan dasar tersebut dicampur dan dibakar dengan suhu $1550^{\circ} \mathrm{C}$ dan menjadi klinker yang kemudian dihaluskan agar menjadi bubuk. Pada umumnya ditambahkan gips atau kalium sulfat (CaSO4) antara 2 - $4 \%$ yang digunakan sebagai bahan pengotrol waktu pengikatan.

b. Agregat

Agregat yang dapat digunakan untuk bahan dasar campuran beton adalah agregat halus (pasir) dan agregat 
kasar (kerikil) yang memenuhi syarat dan standar, dapat diperoleh secara alamiah maupun buatan (manual). Agregat diperoleh melalui deposit alam seperti pasir dan kerikil alam ataupun penggalian. Pasir alam lebih banyak dan ekonomis sebagai bahan dasar. Dua jenis agregat adalah :

1). Agregat halus (pasir alami)

Agregat Halus merupakan bahan pengisi (filler) berupa pasir. Dimana ukurannya bervariasi yaitu antara ukuran saringan No. 4 sampai No. 100 (saringan standar Amerika).

Persyaratan yang digunakan mengenai proporsi agregat dengan gradasi ideal yang direkomendasikan terdapat dalam standar ASTM C 33/ 03 "Standard Spesification for ConcreteAggregates".

2). Àgregat kasar (kerikil, batu pecah, atau pecahan dari blast furnance)

Dalam ASTM C 33-03 dan ASTM C 125-06, agregat kasar adalah agregat dengan ukuran butir lebih besar dari 4,75 $\mathrm{mm}$. Ketentuan yang merupakan standar mengenai agregat kasar antara lain :

a) Terdiri dari butir-butir yang keras dan tidak berpori.

b) Butir- butir agregat kasar harus memiliki sifat kekal, artinya tidak pecah atau hancur yang disebabkan oleh pengaruh-pengaruh cuaca/suhu, seperti sinar matahari dan hujan.

c) Terhindar dari kandungan zat-zat yang dapat merusak beton, seperti zat-zat yang relatif alkali.

d) Tidak mengandung lumpur lebih dari $1 \%$.Apabila kadar lumpur melampaui $1 \%$, maka agregat kasar di rekomendasikan harus dicuci.
Tabel 1. Gradasi Saringan Ideal Agregat Halus

\begin{tabular}{ccc}
\hline $\begin{array}{c}\text { Diameter } \\
\text { Saringan } \\
(\mathbf{m m})\end{array}$ & $\begin{array}{c}\text { Persen } \\
\text { Lolos } \\
(\%)\end{array}$ & $\begin{array}{c}\text { Gradasi } \\
\text { Ideal } \\
(\%)\end{array}$ \\
\hline $9,5 \mathrm{~mm}$ & 100 & 100 \\
\hline $4,75 \mathrm{~mm}$ & $95-100$ & 97,5 \\
\hline $2,36 \mathrm{~mm}$ & $80-100$ & 90 \\
\hline $1,18 \mathrm{~mm}$ & $50-85$ & 67,5 \\
\hline $600 \mu \mathrm{m}$ & $25-60$ & 42,5 \\
\hline $300 \mu \mathrm{m}$ & $5-30$ & 17,5 \\
\hline $150 \mu \mathrm{m}$ & $0-10$ & 5 \\
\hline
\end{tabular}

(Sumber: ASTM C 33/03)

Tabel 2.Gradasi Saringan Ideal Agregat Kasar

\begin{tabular}{ccc}
\hline $\begin{array}{c}\text { DIAMETER } \\
\text { SARINGAN } \\
(\mathbf{M M})\end{array}$ & $\begin{array}{c}\text { PERSEN } \\
\text { LOLOS } \\
(\mathbf{\%})\end{array}$ & $\begin{array}{c}\text { GRADAS } \\
\text { I IDEAL } \\
\mathbf{( \% )}\end{array}$ \\
\hline 25,00 & 100 & 100 \\
\hline 19,00 & $90-100$ & 95 \\
\hline 12,50 & - & - \\
\hline 9,50 & $20-55$ & 37,5 \\
\hline 4,75 & $0-10$ & 5 \\
\hline 2,36 & $0-5$ & 2,5 \\
\hline
\end{tabular}

(Sumber: ASTM C 33/ 03)

3) Air

Dalam campuran beton, air memiliki fungsi yang sangat penting dalam proses pembuatan beton.. Fungsi air pada campuran dalam pembuatan adalah untuk membantu reaksi kimia pada semen dan material lainnya yang menyebabkan beton mudah dikerjakan karena air membantu sebagai pengikatan serta pelicin antara campuran agregat dan semen.

\subsection{Perencanaan Campuran Beton ( MIX DESAIN )}

SK SNI T-15-1990-03 dengan judul buku "Tata cara PembuatanRencana Campuran Beton Normal" merupakan salah satu cara atau metode yang digunakan untuk merencakana mix desain suatu campuran beton.Langkah-langkah yang digunakan dalam perhitungan perencanaan beton dengan adalah sebagai berikut : 
a. Penentuan Kuat Tekan Beton

Rumus yang digunakan dalam menentukan nilai kuat tekan beton pada umur 28 adalah sebagai berikut:

$$
\mathrm{f}^{\prime} \mathrm{cr}=\mathrm{f}^{\prime} \mathrm{c}+1,64 \mathrm{~s}
$$

Dimana :

$\mathrm{f}^{\prime} \mathrm{cr}=$ kuat tekan beton rata- rata $\left(\mathrm{kg} / \mathrm{cm}^{2}\right)$

$\mathrm{f}^{\prime} \mathrm{c}=$ kuat tekan $\left(\mathrm{kg} / \mathrm{cm}^{2}\right)$

$\mathrm{s}=$ standar deviasi $\left(\mathrm{kg} / \mathrm{cm}^{2}\right)$

$\mathrm{m}=$ nilai tambah margin $(\mathrm{kg} / \mathrm{cm})$

b. Penetapan Nilai Standar Deviasi (S)

Penentuan nilai standar deviasi berdasarkan 2 hal yaitu :

1) Menentukan mutu pengendalian pelaksanaan pencampuran beton yaitu semakin kecil nilai standar deviasi yang digunakan maka pengendalian pelaksanaan pencampuran beton pada pelaksanaan semakin baik.

Tabel 3. Mutu pelaksanaan pekerjaan diukur dengan deviasi standar $\left(\mathrm{kg} / \mathrm{cm}^{2}\right)$

\begin{tabular}{ccccc}
\hline \multicolumn{2}{c}{ Volume Pekerjaan } & \multicolumn{3}{c}{ Mutu Pelaksanaan } \\
\hline Ukuran & Satuan (M3) & $\begin{array}{c}\text { Baik } \\
\text { Sekali }\end{array}$ & Baik & $\begin{array}{c}\text { Dapat } \\
\text { Diterima }\end{array}$ \\
\hline Kecil & $<1000$ & $45<\mathrm{S} \leq 55$ & $55<\mathrm{S} \leq 65$ & $65<\mathrm{S} \leq 85$ \\
\hline Sedang & $1000-3000$ & $35<\mathrm{S} \leq 45$ & $45<\mathrm{S} \leq 55$ & $55<\mathrm{S} \leq 75$ \\
\hline Besar & $>3000$ & $25<\mathrm{S} \leq 35$ & $35<\mathrm{S} \leq 45$ & $45<\mathrm{S} \leq 65$ \\
\hline
\end{tabular}

(Sumber: Buku Teknologi Beton, hal.161)

2) Volume pekerjaan (m3) semakin besar akan menghasilkan standar deviasi yang kecil.

Tabel 4. Deviasi Standar (MPa)

\begin{tabular}{cc}
\hline $\begin{array}{c}\text { Tingkat pengendalian } \\
\text { mutu pekerjaan }\end{array}$ & S (MPa) \\
\hline Memuaskan & 2.8 \\
\hline Sangat baik & 3.5 \\
\hline Baik & 4.2 \\
\hline Cukup & 5.6 \\
\hline Jelek & 7.0 \\
\hline Tampa kendali & 8.4 \\
\hline
\end{tabular}

(Sumber : Buku Teknologi Beton, hal.169)

c. Penetapan Jenis Agregat
Jenis agregat kasar dan agregat halus ditetapkan, apakah berupa agregat alami (tak dipecah) ataukah agregat jenis batu pecah.

\section{d. Mencari Faktor Air Semen (FAS )}

Dalam penelitian ini digunakan FAS sebesar 0,5 diambil dari tabel 5 Persyaratan FAS (Buku Teknologi Beton, Hal 169) yang diperoleh berdasarkan pada jenis beton tak bertulang, sebab pada grafik didapatkan nilai faktor air semen yang cukup besar yaitu 0.7 dimana dikhawatirkan akan membuat campuran beton cair atau beton encer. Syarat penggunaan FAS dapat dilihat pada tabel 5.

Tabel 5.Persyaratan FAS

\begin{tabular}{ccc}
\hline Jenis Beton & $\begin{array}{c}\text { Kondisi } \\
\text { Lingkungan }\end{array}$ & FAS Maks \\
\hline Beton Bertulang & Ringan & 0.65 \\
Biasa & Sedang & 0.55 \\
& Berat & 0.45 \\
\hline Pra-tegang & Ringan & 0.65 \\
& Sedang & 0.55 \\
& Berat & 0.45 \\
\hline Beton tak bertulang & Ringan & 0.70 \\
& Sedang & 0.60 \\
& Berat & 0.50 \\
\hline
\end{tabular}

(Sumber: Buku Teknologi Beton, hal.169)

e. Penentuan Nilai Slump

Berdasarkan pemakaian beton penentuan nilai slump untuk jenis kontruksi banguan tertentu dapat lihat Tabel 6, pemakaian beton untuk jenis kontruksi pondasi telapak tidak bertulang kaison, dan struktur di bawah tanah adalah nilai slump yang digunakan pada penelitian ini.

Tabel 6. Penetapan nilai slump 


\begin{tabular}{clcc}
\hline No & \multicolumn{1}{c}{ Pemakaian Beton } & Maks & Min \\
\hline 1 & $\begin{array}{l}\text { Dinding, plat pondasi, } \\
\text { dan pondasi telapak } \\
\text { tulang }\end{array}$ & 12,5 & 5 \\
\hline 2 & $\begin{array}{l}\text { Pondasi telapak tidak } \\
\text { bertulang kaison, dan } \\
\text { struktur di bawah } \\
\text { tanah }\end{array}$ & & \\
\hline 3 & $\begin{array}{l}\text { Pelat, balok, kolom, } \\
\text { dan dinding }\end{array}$ & 15 & 7,5 \\
\hline 4 & Pengeras jalan & 7,5 & 5,2 \\
\hline 5 & Pembetonan massal & 7,5 & 2,5 \\
\hline
\end{tabular}

(Sumber : PBI,1971)

\section{f. Penentuan Nilai Kadar Air Bebas}

Tabel 7. Penentuan Nilai Kadar Air Bebas

\begin{tabular}{cccccc}
\hline \multirow{2}{*}{$\begin{array}{c}\text { Besar Ukuran } \\
\text { Kerikil Maks. }\end{array}$} & Jenis & \multicolumn{4}{c}{ Slump (mm) } \\
\cline { 3 - 6 }$(\mathbf{m m})$ & Batuan & $\mathbf{0 - 1 0}$ & $\mathbf{1 0 - 3 0}$ & $\mathbf{3 0 - 6 0}$ & $\mathbf{6 0 - 1 0 0}$ \\
\hline \multirow{2}{*}{10} & Alami & 150 & 180 & 205 & 225 \\
\cline { 3 - 6 } & $\begin{array}{c}\text { Batu } \\
\text { Pecah }\end{array}$ & 180 & 205 & 230 & 250 \\
\hline \multirow{2}{*}{20} & Alami & 135 & 160 & 180 & 195 \\
\cline { 2 - 6 } & $\begin{array}{c}\text { Batu } \\
\text { Pecah }\end{array}$ & 170 & 190 & 210 & 225 \\
\hline \multirow{2}{*}{40} & Alami & 115 & 140 & 160 & 175 \\
\cline { 2 - 6 } & $\begin{array}{c}\text { Batu } \\
\text { Pecah }\end{array}$ & 155 & 175 & 190 & 205 \\
\hline
\end{tabular}

(Sumber :Buku Teknologi Beton, hal:188)

g. Perhitungan Jumlah Semen

Kebutuhan semen dapat dihitung dan diperoleh dengan menggunakan rumus sebagai berikut:

$$
\text { Kadar Semen }=\frac{F A S}{\text { Kadar air bebas }}
$$

h. Penentuan Berat Jenis Gabungan

Berat jenis gabungan adalah gabungan dari berat jenis material agregat halus dan material agregat kasar dengan prosentase dari campuran agregat tersebut. Berat jenis gabungan dapat dihitung dengan menggunakan rumus sebagai berikut :

$$
B j g a b=\frac{(x a)}{100} x B j x a+\frac{(x b)}{100} x B j x b
$$

Dimana:

Bjgab = Berat jenis gabungan agregat

$\mathrm{Xa}=\%$ agrgat halus

$\mathrm{Xb}=\%$ agregat kasar
Bjxa = Berat jenis spesifik SSD pasir

Bjxa = Berat jenis spesifik SSD kerikil

i. Penentuan Berat Beton Segar

Dalam penentuan berat beton segar dapat dihitung/ditentukan dengan melihat grafik berdasarkan data hasil berat jenis gabungan serta kebutuhan air pengaduk untuk kebutuhan setiap meter kubik.

j. Koreksi Campuran Beton untuk

Pelaksanaan

Koreksi campuran beton yang digunakan untuk pelaksanaan ini dapat dihitung dengan rumus sebagai berikut:

1) Berat lapangan pasir

$$
B L p=\frac{B S S D P}{(1+R p) x(1-W p)}
$$

Dimana:

$$
\begin{array}{ll}
\text { BSSDP } & =\text { Berat Pasir }\left(\mathrm{kg} / \mathrm{m}^{3}\right) \\
\mathrm{Rp} & =\text { Absorbsi Pasir }(\%) \\
\mathrm{Wp} & =\text { Kadar Air Pasir }(\%)
\end{array}
$$

2) Berat lapangan Krikil (BLk)

$$
\mathrm{BLp}=\frac{\mathrm{BSSDK}}{(1+\mathrm{Rk}) *(1-\mathrm{Wk})}
$$

Dimana:

BSSDP $=$ Berat Pasir $\left(\mathrm{kg} / \mathrm{m}^{3}\right)$

$\mathrm{Rk}=$ Absorbsi Krikil (\%)

$\mathrm{Wp}=$ Kadar Air Krikil (\%)

3) Berat lapangan Krikil (BLk)

$B L k=W a+(B S S D p-B L p)+(B S S D k-B L K)$

Dimana:

Wa $=$ Kadar Air Bebas $\left(\mathrm{kg} / \mathrm{m}^{3}\right)$

4. Kuat Tekan Beton

Kuat tekan beton merupakan besarnya beban persatuan luas yang menyebabkan benda uji beton hancur bila 
dibebani dengan menggunakan gaya tekan tertentu, yang dihasilkan oleh mesin tekan (SNI 03- 1974-1990). Hasil massa beban maksimum akan terbaca dalam satuan ton atau KN. Sampel yang diletakkan pada mesin tekan secara sentris. Pembebanan dilakukan secara perlahan-lahan sampai beton mengalami keretakan dan kehancuran.

Nilai kuat tekan beton dapat dihitung menggunakan rumus sebagai berikut :

$$
f^{\prime} c=\frac{P}{A}
$$

Dimana :

$$
\begin{aligned}
\mathrm{f}^{\prime} \mathrm{c}= & \text { Kuat tekan beton dari masing- } \\
& \text { masing benda uji }\left(\mathrm{kg} / \mathrm{cm}^{2}\right) . \\
\mathrm{P}= & \text { Beban Maksimum }(\mathrm{Kg}) . \\
\mathrm{A}= & \text { Luas bidang tekan beton atau } \\
& \text { luas permukaan }\left(\mathrm{cm}^{2}\right) .
\end{aligned}
$$

Standar deviasi (SD) ditentukan berdasarkan tingkat mutu pelaksanaan pekerjaan dilapangan. Semakin baik mutu peralatan dalam pelaksanaan pekerjaan, pengawasan dan pelaksanaannya maka standar deviasi yang ditentukan makin kecil, begitu pula sebaliknya. Standar deviasi ini selanjutnya mempengaruhi perhitungan dalam mencari nilai kuat tekan rata-rata.

Standar deviasi dapat dihitung dengan rumus :

$$
S=\sqrt{\frac{\sum\left(f^{\prime} c-f^{\prime} c m\right.}{n-1}}
$$

Sedangkan untuk menghitung kekuatan tekan beton karakteristik :

$$
f^{\prime} \mathrm{ck}=\mathrm{f}^{\prime} \mathrm{cm}-(\mathrm{kxs}) \ldots(9)
$$

Dimana :

$$
\begin{array}{rl}
\mathrm{f}^{\prime} \mathrm{cm}= & \begin{array}{l}
\text { Kuat tekan beton masing- } \\
\text { masing benda uji }\left(\mathrm{kg} / \mathrm{cm}^{2}\right)
\end{array} \\
\mathrm{f}^{\prime} \mathrm{ck}= & \text { Kuat tekan beton } \\
& \text { karakteristik }\left(\mathrm{kg} / \mathrm{cm}^{2}\right) . \\
\mathrm{n}= & \text { Jumlah benda uji. } \\
\mathrm{S} & \text { Standar deviasi. } \\
\mathrm{K} & 1,64
\end{array}
$$

Bentuk dan ukuran benda uji sangat mempengaruhi nilai kuat tekan beton yang diperoleh. Bentuk standar benda uji menurut Standar Nasional Indonesia adalah silinder berdiameter $15 \mathrm{~cm}$ dan tinggi $30 \mathrm{~cm}$, namun apabila karena alasan tertentu tidak dapat membuat silinder, maka boleh digunakan bentuk kubus sisi $150 \mathrm{~mm}$. Apabila digunakan bentuk kubus sisi $150 \mathrm{~mm}$, maka hasil uji nilai kuat tekannya perlu dikalikan dengan nilai faktor koreksi sebesar 0,83.

\section{METODE PENELITIAN}

\subsection{Tinjauan Umum Penelitian}

Langkah awal dari penelitian ini adalah pemilihan lokasi penelitian, yaitu menentukan daerah penghasil agregat yang akan dijadikan sampel pada penelitian ini. Penggunaan pasir terhadap campuran beton dengan agregat lain yang akan dijadikan sampel pada penelitian ini adalah untuk agregat halus (pasir) berasal dari Desa Rongi dan agregat kasar (krikil) dari Kecamatan Batauga. Pencampuran beton dengan menggunakan material pasir kali sering digunakan oleh masyarakat yang berada pada lokasi pinggiran sungai, khususnya daerah kepulauan, namun belum didasari adanya kepastian tentang berapa besar kualitas beton yang dihasilkan dari pengaruh penggunaan pasir kali terhadap campuran beton di daerah tersebut.

\subsection{Lokasi dan Waktu Penelitian}

Penelitian dilakukan dilaboratorium teknik sipil Universitas Muhammadiyah Buton yang beralamat di jalan Betoambari No 36. Penelitian ini mulai dilaksanakan pada bulan September - Desember 2019

\subsection{Teknik Pengumpulan Data}

Pengambilan material agregat halus (pasir) dan agregat kasar (kerikil) dilakukan secara langsung dilokasi atau daerah penambangan pasir. Hal ini dilakukan agar sampel yang diambil benar-benar langsung bersumber dari 
lokasi tersebut. Sampel kemudian dimasukkan kedalam satu tempat (karung sampel) untuk pemeriksaan data-data karakteristik dan mix design. Lokasi material agregat halus (Pasir) dari kali do Kecamatan Sampolawa dan agregat kasar (krikil) dari kali di Kecamatan Batauga.

\subsection{Pelaksanaan Penelitian}

Metode pelaksanaan penelitian sebagai berikut :

a. Pemeriksaan Karakteristik Agregat

b. Pemeriksaan Beton

c. Perlakuan Terhadap Benda Uji

\section{HASIL PENELITIAN DAN PEMBAHASAN}

a. Karakteristik Material Agregat Halus

Setelah melakukan pengujian diperoleh hasil pemeriksaan karakteristik agregat halus pasir Desa Rongi Kecamatan Sampolawa yang dapat dilihat pada tabel 8 berikut ini :

Tabel 8. Hasil Pemeriksaan Sifat-Sifat Agregat Halus pasir Desa Rongi Kecamatan Sampolawa

\begin{tabular}{cccc}
\hline No & Jenis & Hasil & Satuan \\
& Pemeriksaan & $\begin{array}{c}\text { Pemeriksaan } \\
\text { Desa Rongi }\end{array}$ & \\
\hline 1 & Berat Jenis : & & \\
& $\begin{array}{c}\text { Berat Jenis } \\
\text { Bulk } \\
\text { Berat Jenis } \\
\text { SSD }\end{array}$ & 2,69 & -- \\
& Berat Jenis \\
& Semu & 2,57 & -- \\
& Penyerapan & 2,96 & -- \\
\hline 2 & Berat Isi & 1,54 & $\mathrm{gr} / \mathrm{cm}^{3}$ \\
& Lepas & $\mathrm{gr} / \mathrm{cm}^{3}$ \\
\hline 3 & Berat Isi Padat & 1,70 & $\%$ \\
\hline 4 & Kadar & 1,78 & $\%$ \\
\hline 5 & Lumpur & & \\
\hline
\end{tabular}

Sumber: Hasil analisa data

Tabel 9. Hasil Pemeriksaan Analisa Saringan Agregat Halus

\begin{tabular}{|c|c|c|c|c|}
\hline \multirow[b]{2}{*}{$\begin{array}{c}\text { No } \\
\text { Sari } \\
\text { ngan }\end{array}$} & \multicolumn{4}{|c|}{ Material 1500 Gram } \\
\hline & $\begin{array}{c}\text { Berat } \\
\text { Tertaha } \\
\text { n Rata- } \\
\text { rata } \\
\text { (gr) }\end{array}$ & $\begin{array}{c}\% \\
\text { Terta } \\
\text { han }\end{array}$ & $\begin{array}{c}\% \\
\text { Komu } \\
\text { latif } \\
\text { Terta } \\
\text { han }\end{array}$ & $\begin{array}{c}\% \\
\text { Komu } \\
\text { latif } \\
\text { Lolos }\end{array}$ \\
\hline 1 & 0,00 & 0,0 & 0,00 & 100,00 \\
\hline $3 / 4$ & 0,00 & 0,0 & 0,00 & 100,00 \\
\hline $1 / 2$ & 0,00 & 0,00 & 0,00 & 100,00 \\
\hline $3 / 8$ & 0,00 & 8 & 0,00 & 100,00 \\
\hline$\square$ & 0,00 & 0,0 & 0,00 & 100,00 \\
\hline$\square$ & 5,00 & 03 & 0,33 & 99,67 \\
\hline$\square \square$ & 35,00 & 2,3 & 2,67 & 97,33 \\
\hline $\begin{array}{ll}\square \\
\end{array}$ & 230,00 & 15,33 & 18,00 & 82,00 \\
\hline $\begin{array}{ll}\square \\
\end{array}$ & 610,00 & 40,67 & 58,67 & 41,33 \\
\hline 100 & 595 & 39,67 & 98,33 & 1,67 \\
\hline Pan & 25,00 & 1,67 & 100,00 & 0,00 \\
\hline
\end{tabular}

Sumber: Hasil analisa data

Tabel 11. Hasil Analisa Saringan Agregat Kasar

\begin{tabular}{ccccc}
\hline $\begin{array}{c}\text { No. } \\
\text { Saringan }\end{array}$ & \multicolumn{4}{c}{ Material 2400 Gram } \\
\cline { 2 - 5 } & $\begin{array}{c}\text { Berat } \\
\text { Tertahan } \\
(\mathbf{G r})\end{array}$ & $\begin{array}{c}\text { Persen } \\
\text { Tertahan } \\
\mathbf{( \% )}\end{array}$ & $\begin{array}{c}\text { Tertahan } \\
\%\end{array}$ & $\begin{array}{c}\text { Lewat } \\
\%\end{array}$ \\
\hline $11 / 2^{\prime \prime}$ & 0,00 & 0,00 & 0,00 & 100,00 \\
\hline $1^{\prime \prime}$ & 30,00 & 1,25 & 1,25 & 98,75 \\
\hline $3 / 4^{\prime \prime}$ & 815,00 & 33,96 & 35,21 & 64,79 \\
\hline $1 / 2^{\prime \prime}$ & 950,00 & 39,58 & 74,79 & 25,21 \\
\hline $3 / 8^{\prime \prime}$ & 335,00 & 13,96 & 88,75 & 11,25 \\
\hline 4 & 200,00 & 8,33 & 97,08 & 2,92 \\
\hline 8 & 45,00 & 1,88 & 98,96 & 1,04 \\
\hline 16 & 0,00 & 0,00 & 98,96 & 1,04 \\
\hline 30 & 5,00 & 0,21 & 99,17 & 0,83 \\
\hline 50 & 5,00 & 0,21 & 99,38 & 0,63 \\
\hline PAN & 15,00 & 0,63 & 100.00 & 0.00 \\
\hline
\end{tabular}

Sumber: Hasil analisa data

Berdasarkan spesifikasi diatas, maka hasil pemeriksaan analisa saringan Agregat Kasar (Kerikil) Desa Burukena masuk dalam daerah Gradasi Standar Agregat dengan butiran maksimum $40 \mathrm{~mm}$.

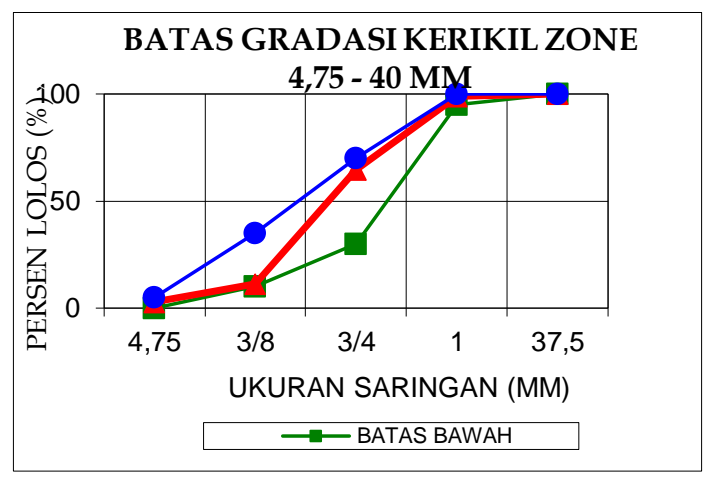


Gambar 2. Batas gradasi kerikil

b. Air

Air yang digunakan dalam melakukan penelitian ini adalah air PDAM Kota Baubau.

c. Semen

Semen yang digunakan pada penelitian ini adalah semen yang umum digunakan untuk konstruksi bangunan beton dan banyak tersedia dipasaran yaitu jenis semen yang diproduksi pabrik semen Tonasa.

\section{d. Hasil Pemeriksaan Komposisi Agregat dari Hasil Uji Karateristik Agregat}

Dari perbandingan perancangan komposisi campuran diperoleh proporsi material untuk beton 27, 97\% agregat halus dan $72,03 \%$ agregat kasar, persentase pemakaian agregat kasar lebih dominan dibanding dengan agregat halus. Dalam susunan unsur pengisi beton, agregat kasar menjadi bahan pengisi utama, sedangkan agregat halus lebih berfungsi sebagai pengisi pori.

e. Perencanaan Mix Design

Tabel 12. Perencanaan mix design untuk komposisi 27,97/72,03 pada FAS 0,54.

\begin{tabular}{ccccc}
\hline $\begin{array}{c}\text { BAHAN } \\
\text { BETON }\end{array}$ & $\begin{array}{c}\text { BERAT/M } \\
\text { BETON } \mathbf{( k g )}\end{array}$ & $\begin{array}{c}\text { RASIO } \\
\text { TERHADAP } \\
\text { JML. SEMEN }\end{array}$ & $\begin{array}{c}\text { BERAT } \\
\text { UTK 1 } \\
\text { SAMPEL } \\
\mathbf{( k g )}\end{array}$ & $\begin{array}{c}\text { BERAT } \\
\text { UTK } \\
\text { 9 SAMPEL } \\
\text { (kg) }\end{array}$ \\
\hline Air & 184,54 & 0,54 & 0,98 & 16,63 \\
\hline Semen & 341,33 & 1,00 & 1,81 & 30,76 \\
\hline Pasir & 501,19 & 1,47 & 2,66 & 45,17 \\
\hline Kerikil & 1265,94 & 3,71 & 6,71 & 114,09 \\
\hline
\end{tabular}

Sumber: Hasil analisa data

\section{f. Hasil Pengujian Kuat Tekan}

Hasil pengujian yang dilakukan terhadap benda uji diperoleh nilai kuat tekan rata-rata beton pada tiap-tiap umur pengujian berdasarkan komposisi perbandingan agregat :

Tabel 13. Hasil Pengujian Kuat Tekan Rata-rata.

\begin{tabular}{ccc}
\hline No & Umur & $\begin{array}{c}\text { Kuat Tekan } \\
\mathbf{( K g / c m 2 )}\end{array}$ \\
\hline 1 & Umur 3 hari & 94,5 \\
\hline 2 & Umur 7 hari & 119,6 \\
\hline 3 & Umur 28 hari & 192,5 \\
\hline
\end{tabular}

Sumber: Hasil analisa data

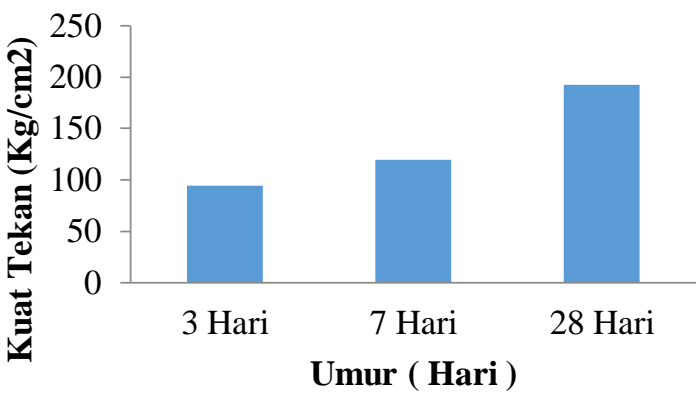

Gambar 3. Grafik perbandingan kuat tekan pada umur 3 hari, 7 hari dan umur 28 hari.

Berdasarkan grafik di atas dapat dilihat terjadinya peningkatan kuat tekan rata-rata beton dengan menggunakan material yang berasal dari Desa Rongi. Kuat tekan beton material umur 3 hari sebesar $94.5 \mathrm{Kg} / \mathrm{Cm} 2$, umur 7 hari sebesar $119.6 \mathrm{Kg} / \mathrm{Cm} 2$, dan umur 28 hari sebesar $192.5 \mathrm{Kg} / \mathrm{Cm} 2$. Berdasarkan hasil kuat tekan pada grafik di atas beton mengalami peningkatan sering bertambahnya umur perawatan beton.

\section{KESIMPULAN}

Berdasarkan hasil penelitian Pada Laboratorium Struktur dan Konstruksi Teknik Sipil Fakultas Teknik Universitas Muhammadiyah Buton, penulis dapat mengambil kesimpulan yaitu hasil pengujian karakteristik agregat halus dari Desa Rongi dan agregat kasar dari Desa Burukene yang diperoleh melalui hasil pemeriksaan masing - masing jenis pemeriksaan ada yang masuk dalam standar namun ada juga yang tidak masuk standar pemeriksaan yang disyaratkan. Hasil pengujian uji karakteristik pasir yaitu kadar lumpur pasir $1.78 \%$, kadar air pasir $4.25 \%$, berat volume pasir kondisi lepas 1.54 dan kondisi padat 1.70, berat jenis pasir nyata 2.69, berat jenis pasir 
dasar kering 2.50, berat jenis pasir kering permukaan 2.57, modulus kehalusan 2.64 serta absorpsi $2.96 \%$. Sedangkan kadar lumpur kerikil $0.24 \%$, kadar air kerikil $1.08 \%$, berat volume kerikil kondisi lepas 1.20 , berat volume kondisi padat 1.48 , absorpsi $1.63 \%$, berat jenis nyata kerikil 2.53, berat jenis kerikil dasar kering 2.43, berat jenis kerikil kering permukaan 2.47 dan modulus kekasaran 6.94.

Dari hasil pengujian kuat tekan beton yang dilakukan pada umur 3 hari diperoleh nilai kuat tekan sebesar $94.5 \mathrm{Kg} / \mathrm{Cm} 2$, umur 7 hari sebesar 119.6 $\mathrm{Kg} / \mathrm{Cm} 2$, dan umur 28 hari sebesar 192.5 $\mathrm{Kg} / \mathrm{Cm} 2$. Berdasarkan hasil pengujian kuat tekan beton yang dihasilkan, menunjukan bahwa nilai kuat tekan beton meningkat seiring dengan bertambahnya umur perawatan beton.

\section{DAFTAR PUSTAKA}

Anonim. (2010). Buku Teknologi Beton. Bidang Pengujian dan Pengembangan Teknologi

ASTM C 33/03. Standard Spesification For Concrete aggregates.

SK SNI T-15-1990-03 dengan judul buku "Tata cara Pembuatan Rencana Campuran Beton Normal".

SK SNI 03-1974-1990 dengan judul buku "Tata cara Pembuatan Rencana Campuran Beton Normal".

SK SNI-03-2847-2002 "Tata cara Pembuatan Rencana Campuran Beton Normal".

Tjokrodimuljo, K. (1996). Buku Teknologi Beton. Yogyakarta: Nafiri, Yogyakarta. 